\title{
APLIKASI SISTEM PAKAR PENDETEKSI KERUSAKAN LAPTOP/PC DENGAN PENERAPAN METODE FORWARD CHAINING MENGGUNAKAN BAHASA PEMROGRAMAN PHP
}

\author{
Hasanah $^{1}$, Ridarmin ${ }^{2}$, Sukri Adrianto ${ }^{3}$ \\ ${ }^{1,2,3}$ Sekolah Tinggi Manajemen Informatika dan Komputer (STMIK) Dumai \\ Jln. Utama Karya Bukit Batrem Dumai-Riau Kode Pos 28811 \\ e-mail : $\underline{\text { anahani88@gmail.com }}$
}

\begin{abstract}
ABSTRAK
Besarnya rasa ingin tahu user untuk melakukan perbaikan laptop/PC yang mereka miliki secara mandiri, serta kurangnya pengetahuan user tentang perangkat komputer khususnya perangkat hardware membuat proses perbaikan menjadi lambat. Pembuatan aplikasi ini menggunakan bahasa pemrograman PHP dan menggunakan database MySQL sebagai penyimpanan data. data-data yang diperoleh dari pakar atau orang yang ahli dibidang kerusakan laptop/PC, data akan diinputkan kedalam database, dan kemudian data diolah sehingga dapat menampilkan hasil analisa dan solusi untuk perbaikan yang akan dilakukan. Metode yang digunakan adalah metode forward chaining, metode forward chaining merupakan teknik pencarian yang dimulai dengan fakta yang diketahui, kemudian mencocokkan faktafakta tersebut dengan bagian IF dari rules IF-THEN.Dengan adanya aplikasi ini diharapkan agar dapat mempermudah user mendeteksi kerusakan yang terjadi sehingga dapat melakukan penanganan yang diperlukan secara lebih cepat dan lebih akurat.
\end{abstract}

Kata Kunci : sistem pakar, kerusakan laptop/PC, PHP, forward chaining, aplikasi

\section{PENDAHULUAN}

Kemajuan teknologi komputer pada saat ini berkembang dengan sangat pesat, teknologi sudah memberi pengaruh yang sangat penting dalam kehidupan sehari-hari dimana hampir seluruh kegiatan yang dilakukan tidak terlepas dari teknologi khususnya teknologi komputer. Dengan pesatnya perkembangan teknologi komputer para penemu dan pengembang komputer telah mencari berbagai cara untuk memudahkan user dalam menggunakannya, salah satunya adalah laptop/PC.

Laptop atau komputer jinjing, atau notebook, merupakan sebuah mobile computer yang berukuran relatif kecil dan ringan. Beratnya berkisar 1-3 kg, tergantung ukuran, bahan, dan spesifikasi laptop tersebut. Sumber daya laptop berasal dari baterai atau adaptor $A / C$. Baterai laptop pada umumnya dapat bertahan sekitar 1- 6 jam sebelum akhirnya habis, tergantung dari cara pemakaian, spesifikasi, dan ukuran baterai,(Setyaji, 2010)

$P C$ atau Personal Computer merupakan seperangkat komputer yang digunakan oleh satu orang saja/pribadi biasanya komputer ini terdapat dilingkungan rumah, kantor, toko dan dimana saja karena harga $P C$ sudah relatif terjangkau. penggunaan $P C$ sudah menjamur oleh karena itu banyak user yang membutuhkan bantuan dalam melakukan perbaikan pada $P C$ mereka.

Sistem pakar merupakan sebuah solusi untuk user dalam menangani kerusakan pada laptop/PC karena keahlian seorang pakar yang tersimpan didalam database. yang akan menginformasikan secara akurat letak kerusakan-kerusakan yang terjadi pada laptop/PC sehingga dapat membantu user dalam melakukan perawatan pada laptop/ $P C$ nya. Data dari pakar dikumpulkan dari teknisi yang berpengalaman selama bertahun-tahun yaitu teknisi di Laksamana komputer. Laksamana Komputer Dumai merupakan badan usaha yang bergerak dibidang pelayanan jasa, yaitu sales dan services komputer yang berada dikota Dumai.

Tujuan dari penelitian adalah Untuk mendeteksi sumber kerusakan laptop/PC dan melakukan perbaikan tepat sasaran, tetapi aplikasi ini tidak dibuat secara sembarangan tetapi dengan meminta saran langsung dari pakarnya. penelitian ini juga bertujuan untuk membantu user melakukan penanganan yang 


\section{N F O R M A I K}

Jurnal Informatika, Manajemen dan Komputer, Vol. 9 No. 2 , Desember 2017

eISSN : 1979-0694

pISSN : 1979-0694

tepat dalam mendeteksi kerusakan hardware laptop/PC.

\section{a. Komputer}

Secara luas, komputer dapat didefenisikan sebagai suatu peralatan elektronik yang terdiri dari beberapa komponen, yang dapat bekerja sama antara komponen satu dengan komponen yang lain untuk menghasilkan suatu informasi berdasarkan program dan data yang ada. adapun komponen komputer meliputi : layar monitor, CPU, keyboard, Mouse, dan Printer (sebagai pelengkap), (Setyaji, 2010)

\section{b. Laptop}

Laptop atau komputer jinjing, atau notebook, merupakan sebuahmobile computer yang berukuran relatif kecil dan ringan. Beratnyaberkisar 1-3 kg, tergantung ukuran, bahan, dan spesifikasi laptop tersebut,(Setyaji, 2010).

\section{c. Sistem Komputerisasi}

Sistem komputerisasi adalah penggunaan komputer sebagai alat Bantu dalam kegiatan pengolahan data yang dilakukan secara manual. Data diolah dengan menggunakan computer yang sudah deprogram sebelumnya, pengolahan data ini dimulai dengan perekam data hingga sampai pada pencetakan laporan. Pengolahan data secara komputerisasi lebih menguntungkan dibandingkan dengan pengolahan data secara manual. Keuntungan tersebut dapat ditinjau dari beberapa segi. Salah satu dalam hal penyajian laporan yang lebih cepat dan efisien dan akurat. Faktor keuntungan inilah yang menjadi alasan mengapa pengolahan data dilakukan secara komputerisasi untuk menggantikan sistem manual.(Cilla Mondev, Asparizal, \& Adrianto, 2017)

\section{d. Sistem Pakar}

Menurut (Rosnelly, 2012), Profesor Edward Feigenbaum dari Stanford University yang merupakan pionir dalam teknologi sistem pakar mendefenisikan sistem pakar sebagai sebuah program komputer pintar (Intelegent Computer Program) yang memanfaatkan pengetahuan (knowledge) dan prosedur inferensi (Inference procedure) untuk memecahkan masalah yang cukup sulit hingga membutuhkan keahlian khusus dari manusia.Dengan kata lain sistem pakar adalah sistem komputer yang ditujukan untuk meniru semua aspek (emulates) kemampuan pengambilan keputusan (decision making) seorang pakar.
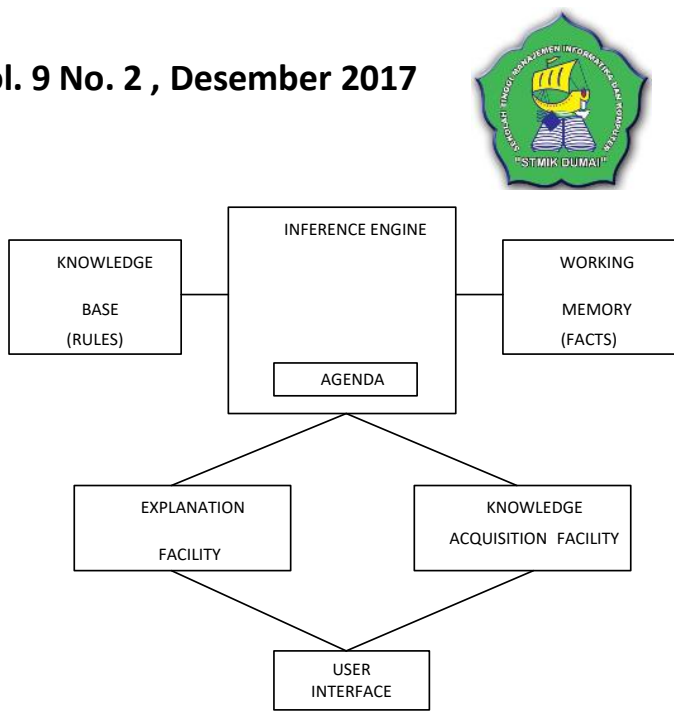

Gambar 1.Struktur Sistem Pakar Sumber : (Rosnelly, 2012)

\section{e. Forward Chaining}

Forward Chaining adalah teknik pencarian yang dimulai dengan fakta yang diketahui, kemudian mencocokkan fakta-fakta tersebut dengan bagian IF dari rules IFTHEN.Bila ada fakta yang cocok dengan bagian IF, maka rule tersebut dieksekusi.Bila sebuah rule dieksekusi maka sebuah fakta baru (bagian THEN) ditambahkan ke dalam database.Setiap kali pencocokan, dimulai dari rule teratas.Setiap rule hanya boleh dieksekusi sekali saja. Proses pencocokan berhenti bila tidak ada lagi rule yang bias dieksekusi. Metode pencarian yang digunakan Depth-Firs Search (BFS) atau Best Firts Search.(Sutojo, T, 2011)

\section{f. $\quad M y S Q L$}

MySQL adalah sebuah perangkat lunak sistem manajemen basis data SQL(bahasa Inggris: database management system) atau DBMS yang multithread, multi-user, dengan sekitar 6 juta instalasi di seluruh dunia. MySQL $\mathrm{AB}$ membuat MySQL tersedia sebagai perangkat lunak gratis di bawah lisensi GNU General Public License (GPL), tetapi mereka juga menjual dibawah lisensi komersial untuk kasus-kasus dimana penggunaannya tidak cocok dengan penggunaan GPL.Tidak seperti PHP atau Apache yang merupakan software yang dikembangkan oleh komunitas umum, dan hak cipta untuk kode sumber dimiliki oleh penulisnya masing-masing, MySQL dimiliki dan disponsori oleh sebuah perusahaan komersial Swedia yaitu MySQL AB. (Achmad Solihin, 2010).

\section{g. $\quad P H P$}

PHP merupakan bahasa pemrograman yang ditujukan untuk membuat aplikasi web.Ditinjau dari pemrosesannya, PHP tergolong berbasis server side. Artinya, 


\section{INFORMA TIK}

Jurnal Informatika, Manajemen dan Komputer, Vol. 9 No. 2 , Desember 2017

eISSN : 1979-0694

pISSN : 1979-0694

pemrosesan dilakukan di server.Hal ini berkebalikan dengan bahasa seperti javascript, yang pemrosesannya dilakukan di sisi klien. PHP sering dikatakan sebagai bahasa untuk membuat aplikasi web yang dinamis.Pengertian dinamis di sisni adalah memungkinkan untuk menampilkan data yang tersimpan dalam database.Dengan demikian, halaman web akan menyesuaikan dengan isi database.(Abdul Kadir, 2013)

\section{METODOLOGI PENELITIAN}

Metode penelitan yang digunakan dalam penelitian ini adalah sebagai berikut :

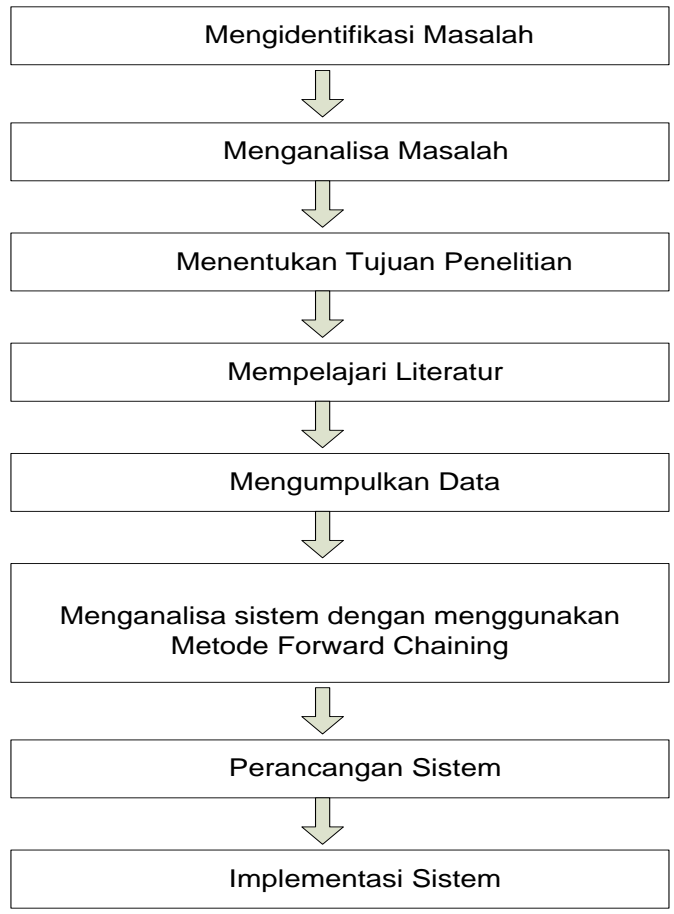

Gambar 5. Kerangka Kerja

Berikut ini penjelasan dari metode penelitian diatas:

1. Mengidentifikasi masalah yang terjadi diantaranya, besarnya rasa ingin tahu user untuk memperbaiki laptop/PC yang dimilikinya secara mandiri, serta kurangnya pengetahuan user tentang masalah kerusakan yang terjadi sehingga membuat proses perbaikan menjadi lambat.

2. Setelah menemukan sumber masalah, langkah selanjutnya adalah menganalisa masalah untuk mencari penyelesaian permasalahan.

3. setelah menganalisa masalah maka akan didapat tujuan dari diadakannya penelitian.

4. Setelah tujuan penelitian diperoleh maka dilakukan pembelajaran literatur dari berbagai sumber.

5. Kemudian dilakukan pengumpulan data dari berbagai sumber buku-buku maupun jurnal-jurnal untuk mepelajari metodemetode yang dibutuhkan.

6. menganalisa metode yang digunakan yaitu metode forward chaining. berdasarkan berbagai sumber yang sudah diperoleh.

7. Setelah mempelajari metode yang digunakan kemudian dilakukan perancangan sistem untuk pembuatan aplikasi.

8. Setelah aplikasi dibuat maka dilakukan implementasi sistem pada tempat yang telah ditentukan.

\section{HASIL DAN PEMBAHASAN}

Context Diagram adalah gambaran sistem secara logikal, gambaran ini tidak tergantung pada perangkat keras, perangkat lunak, atau organisasi file. Suatu context diagram selalu mengandung satu proses saja (diberi nomor proses 0 ), proses ini mewakili proses dari keseluruhan sistem.(Annisaa \& Hidayatullah, 2017)

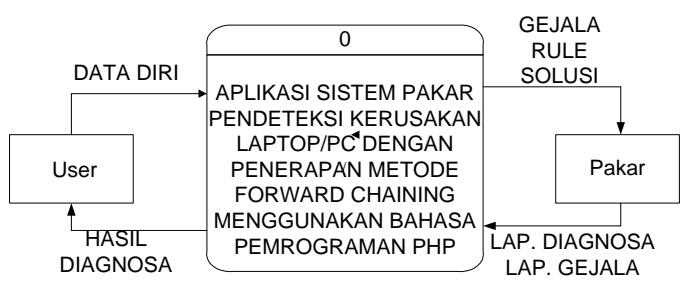

Gambar 7 Context Diagram

Berikut ini penjelasan dari Context Diagram diatas :

1. User dapat mengakses aplikasi sistem pakar secara offline.

2. Setelah dapat mengakses user dapat menginput gejala-gejala kerusakan Laptop/Pc.

3. Selanjutnya dari data gejala yang telah diinput tamu user dapat mengetahui jenis kerusakan pada Laptop/PC.

4. Pakar menginputkan gejala-gejala, jenis kerusakan, dan solusi melalui aplikasi sistem pakar.

5. Pakar dapat mengetahui setiap pengunjung aplikasi sistem pakar, serta kerusakan yang dialami user.

a. DFD (Data Flow Diagram) 
IN F O R M A I I A

Jurnal Informatika, Manajemen dan Komputer, Vol. 9 No. 2 , Desember 2017

eISSN : 1979-0694

pISSN : 1979-0694

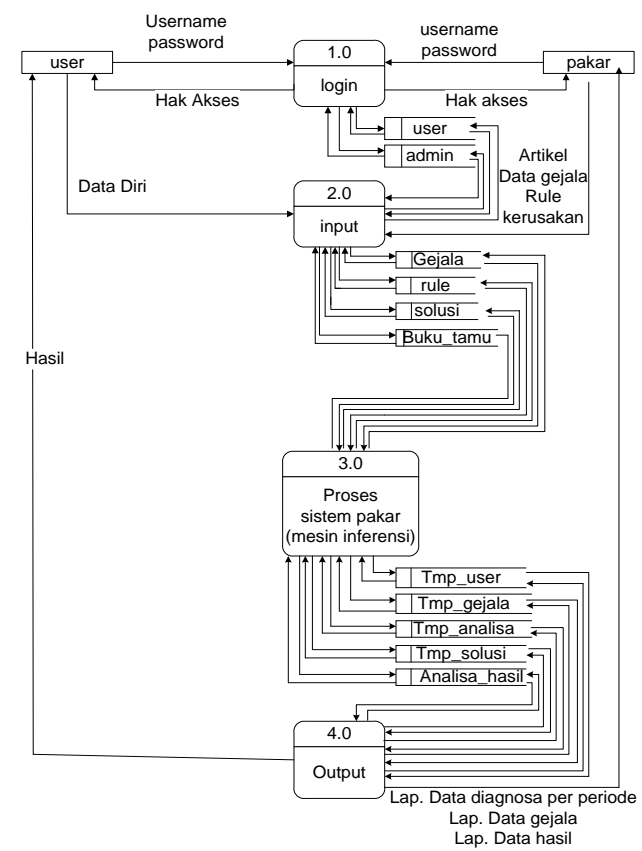

Gambar 8. Data Flow Diagram

b. Rancangan Sistem Usulan (Algoritma)

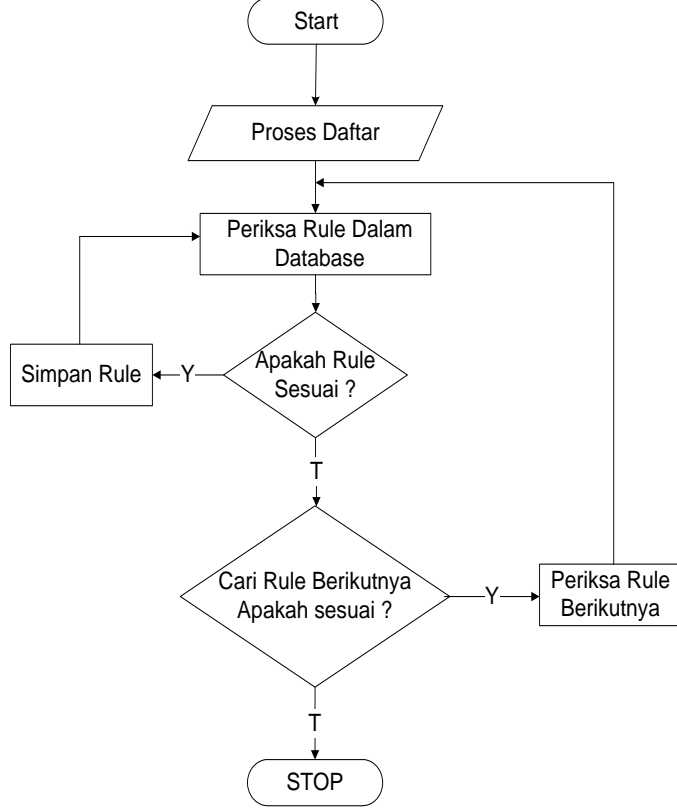

Gambar 9. Algoritma Sistem Pakar Pendeteksi Kerusakan Laptop/PC

c. Daftar Kerusakan

Tabel 1. Tabel Daftar Kerusakan Laptop/PC

\begin{tabular}{|c|c|l|}
\hline No & $\begin{array}{c}\text { Kode } \\
\text { Gejala }\end{array}$ & \multicolumn{1}{|c|}{ Nama Kerusakan } \\
\hline 1 & G001 & $\begin{array}{l}\text { Koneksi kabel antara cpu } \\
\text { dan monitor sudah } \\
\text { terpasang dengan benar. }\end{array}$ \\
\hline 2 & G002 & $\begin{array}{l}\text { Pemasangan kabel pada } \\
\text { sumber }\end{array}$ \\
\hline
\end{tabular}

\begin{tabular}{|c|c|c|}
\hline No & $\begin{array}{l}\text { Kode } \\
\text { Gejala }\end{array}$ & Nama Kerusakan \\
\hline & & $\begin{array}{l}\text { listrik/colokan sudah } \\
\text { terpasang dengan benar. }\end{array}$ \\
\hline 3 & G003 & $\begin{array}{l}\text { power supply rusak: } \\
\text { a. meskipun pemasangan } \\
\text { kabel sudah benar namun } \\
\text { pc tetap tidak menyala } \\
\text { b. lampu indikator pada } \\
\text { cpu tidak menyala } \\
\text { c. PC menyala tapi tidak } \\
\text { mau masuk ke windows }\end{array}$ \\
\hline 4 & G004 & $\begin{array}{l}\text { Baterai pada Laptop habis } \\
\text { / kosong }\end{array}$ \\
\hline 5 & G005 & $\begin{array}{l}\text { Ac Adaptor laptop rusak: } \\
\text { a. lampu indikator listrik } \\
\text { pada laptop tidak } \\
\text { menyala } \\
\text { b. tidak ada arus keluar } \\
\text { dari kabel output adaptor } \\
\text { pada kabel power laptop }\end{array}$ \\
\hline 6 & G006 & $\begin{array}{l}\text { De Jack terlepas/Rusak } \\
: \text { Dc jack merupakan } \\
\text { komponen yang terdapat } \\
\text { pada laptop sebagai } \\
\text { lubang colokan antara } \\
\text { listrik } \\
\text { dan laptop yang terletak } \\
\text { pada motherboard }\end{array}$ \\
\hline 7 & G007 & $\begin{array}{l}\text { RAM Rusak: } \\
\text { RAM merupakan tempat } \\
\text { penyimpanan sementara } \\
\text { pada laptop/pc } \\
\text { a. komputer sering mati } \\
\text { tiba-tiba atau mendadak } \\
\text { b. memori pada kompuer } \\
\text { tidak terdeteksi atau } \\
\text { berkurang a komputer } \\
\text { c. saat ka } \\
\text { dihidupkan hanya muncul } \\
\text { layar hitam } \\
\text { d. komputer terasa } \\
\text { lelet/lambat }\end{array}$ \\
\hline 8 & G008 & $\begin{array}{l}\text { RAM atau memory } \\
\text { tempat penyimpanan } \\
\text { sementara baru diganti, } \\
\text { tapi tidak sesuai dengan } \\
\text { jenis PC/Laptop }\end{array}$ \\
\hline 9 & G009 & $\begin{array}{l}\text { Boot sector pada harddisk } \\
\text { rusak: } \\
\text { gagal pada saat loading } \\
\text { windows/OS atau proses } \\
\text { penyimpanan data } \\
\text { menjadi lambat }\end{array}$ \\
\hline 10 & G010 & Ada bad sector pada track \\
\hline
\end{tabular}


I N F O R M A T I K A

Jurnal Informatika, Manajemen dan Komputer, Vol. 9 No. 2 , Desember 2017

eISSN : 1979-0694

pISSN : 1979-0694

\begin{tabular}{|c|c|c|}
\hline No & $\begin{array}{l}\text { Kode } \\
\text { Gejala }\end{array}$ & Nama Kerusakan \\
\hline & & $\begin{array}{l}\text { awal harddisk: } \\
\text { a. Proses penyimpanan } \\
\text { data menjadi lambat } \\
\text { b. komputer sering } \\
\text { hang/berhenti saat } \\
\text { penyimpanan data } \\
\text { berlangsung } \\
\text { namun laptop/pc tetap } \\
\text { tidak menyala } \\
\text { c. laptop/pc sering restart } \\
\text { atau mati mendadak } \\
\text { c. sering terjadi blue } \\
\text { screen/ layar biru pada } \\
\text { laptop/pc } \\
\text { d. terdengar suara berisik } \\
\text { pada laptop/pc khususnya } \\
\text { pada hardisk } \\
\text { e. loading lambat saat } \\
\text { menyalakan laptop/pc }\end{array}$ \\
\hline 11 & G011 & $\begin{array}{l}\text { Sistem } \\
\text { bermasalah : } \\
\text { a. terjadi masalah saat } \\
\text { masuk ke windows } \\
\text { b. aplikasi windows } \\
\text { explorer tidak dapat } \\
\text { dijalankan } \\
\text { c. proses mematikan } \\
\text { laptop terhenti pada saat } \\
\text { laptop belum benar benar } \\
\text { mati }\end{array}$ \\
\hline 12 & G012 & Hard disk bermasalah \\
\hline 13 & G013 & Harddisk rusak \\
\hline 14 & G014 & $\begin{array}{l}\text { Software mengalami } \\
\text { crash : aplikasi menjadi } \\
\text { macet / berhenti bekerja } \\
\text { secara tiba-tiba, } \\
\text { biasanya tampil } \\
\text { pemberitahuan aplikasi } \\
\text { berhenti bekerja }\end{array}$ \\
\hline 15 & G015 & $\begin{array}{l}\text { ketika penambahan } \\
\text { hardware baru Laptop/PC } \\
\text { sering terjadi konflik atau } \\
\text { laptop/pc menjadi hang } \\
\text { atau sering mati } \\
\text { mendadak }\end{array}$ \\
\hline 16 & G016 & Ada virus di harddisk \\
\hline 17 & G017 & $\begin{array}{l}\text { Keyboard tidak terpasang } \\
\text { dengan benar }\end{array}$ \\
\hline 18 & G018 & Keyboard rusak \\
\hline 19 & G019 & $\begin{array}{l}\text { Setting/pengaturan } \\
\text { Keyboard tidak benar }\end{array}$ \\
\hline 20 & G020 & $\begin{array}{lll}\text { colokan } & \text { usb } & \text { yang } \\
\text { terhubung } & & \text { pada } \\
\end{array}$ \\
\hline
\end{tabular}

\begin{tabular}{|c|c|c|}
\hline No & $\begin{array}{l}\text { Kode } \\
\text { Gejala }\end{array}$ & Nama Kerusakan \\
\hline & & $\begin{array}{l}\text { motherboard } \\
\text { kerusakan }\end{array}$ \\
\hline 21 & G021 & $\begin{array}{l}\text { Driver keyboard tidak } \\
\text { cocok }\end{array}$ \\
\hline 22 & G022 & Keyboard tidak terdeteksi \\
\hline 23 & G023 & $\begin{array}{l}\text { Mouse tidak terpasang } \\
\text { dengan benar }\end{array}$ \\
\hline 24 & G024 & Mouse rusak \\
\hline 25 & G025 & $\begin{array}{l}\text { Setting/pengaturan } \\
\text { Mouse tidak benar }\end{array}$ \\
\hline 26 & G026 & $\begin{array}{l}\text { colokan mouse yang } \\
\text { terletak pada motherboard } \\
\text { rusak }\end{array}$ \\
\hline 27 & G027 & Driver mouse tidak cocok \\
\hline 28 & G028 & Mouse tidak terdeteksi \\
\hline 29 & G029 & $\begin{array}{l}\text { Baterai Cmos mati : } \\
\text { a. settingan/pengaturan } \\
\text { jam pada laptop/pc tidak } \\
\text { benar, tidak mengikuti } \\
\text { jam pada saat ini } \\
\text { b. saat loading windows } \\
\text { terdapat } \\
\text { informasi/pemberitahuan } \\
\text { setup ulang pada BIOS }\end{array}$ \\
\hline 30 & G030 & $\begin{array}{l}\text { VGA Card rusak: } \\
\text { a. laptop/PC macet ketika } \\
\text { berkerja terutama saat } \\
\text { edit video atau memutar } \\
\text { video dan memainkan } \\
\text { game } \\
\text { b. muncul gambar } \\
\text { semu/garis-garis pada } \\
\text { laptop/PC laptop/PC } \\
\text { c. Monitor menampilkan } \\
\text { tidak gambar sama sekali } \\
\text { gam }\end{array}$ \\
\hline 31 & G031 & $\begin{array}{lr}\text { Jumper } & \text { Cmos } \\
\text { Motherboard } & \text { salah } \\
\text { pasang : } & \\
\text { Jumper digunakan untuk } \\
\text { konektor /penghubung } \\
\text { sirkuit elektrik yang } \\
\text { digunakan } \\
\text { untuk menghubungkan } \\
\text { atau memutus suatu } \\
\text { sirkuit, jumper cmos } \\
\text { biasanya terletak } \\
\text { didekat baterai cmos } \\
\text { biasanya terdapat tiga } \\
\text { kaki/pin pada jumper ini. }\end{array}$ \\
\hline 32 & G032 & $\begin{array}{l}\text { motherboard / papan } \\
\text { induk rusak }\end{array}$ \\
\hline
\end{tabular}


I N F O R M A T I K A

Jurnal Informatika, Manajemen dan Komputer, Vol. 9 No. 2 , Desember 2017

eISSN : 1979-0694

pISSN : 1979-0694

\begin{tabular}{|c|c|c|}
\hline No & $\begin{array}{l}\text { Kode } \\
\text { Gejala }\end{array}$ & Nama Kerusakan \\
\hline 33 & G033 & $\begin{array}{l}\text { Cok power listrik atau } \\
\text { stavol longgar }\end{array}$ \\
\hline 34 & G034 & $\begin{array}{l}\text { Set up driver untuk } \\
\text { monitor tidak tepat }\end{array}$ \\
\hline 35 & G035 & Suhu Pc terlalu panas \\
\hline 36 & G036 & Hardisk penuh \\
\hline 37 & G037 & $\begin{array}{lll}\begin{array}{l}\text { Stroom listrik } \\
\text { berfungsi }\end{array} & \text { tidak } \\
\end{array}$ \\
\hline 38 & G038 & $\begin{array}{l}\text { Kabel power switch } \\
\text { casing belum/salah } \\
\text { pasang pada motherboard }\end{array}$ \\
\hline 39 & G039 & memory tidak cukup \\
\hline 40 & G040 & $\begin{array}{lr}\text { Memory/RAM tidak } \\
\text { masuk slot dengan } \\
\text { sempurna }\end{array}$ \\
\hline 41 & G041 & $\begin{array}{l}\text { Slot VGA tidak terpasang } \\
\text { sempurna }\end{array}$ \\
\hline 42 & G042 & kipas pendingin rusak \\
\hline
\end{tabular}

\begin{tabular}{|c|l|l|}
\hline Rule & \multicolumn{1}{|c|}{$\boldsymbol{I F}$} & \multicolumn{1}{|c|}{ THEN } \\
\hline 15 & G003, G033, G035 & K015 \\
\hline 16 & G016, G036, G039 & K016 \\
\hline 17 & G007, G008, G040 & K017 \\
\hline 18 & G030, G041 & K018 \\
\hline 19 & G013, G042 & K019 \\
\hline
\end{tabular}

e. Aturan-aturan (Rules)

Table 3. Aturan-aturan (Rules)

\begin{tabular}{|c|c|}
\hline IF & $\begin{array}{l}\text { Koneksi kabel antara cpu dan } \\
\text { monitor sudah terpasang dengan } \\
\text { benar.AND Pemasangan kabel } \\
\text { pada sumber arus listrik/colokan } \\
\text { sudah terpasang dengan benar. } \\
\text { AND power supply rusak : a. } \\
\text { meskipun pemasangan kabel } \\
\text { sudah benar namun pc tetap tidak } \\
\text { menyala b. lampu indikator pada } \\
\text { cpu tidak menyala.c. PC menyala } \\
\text { tapi tidak mau masuk ke windows }\end{array}$ \\
\hline THEN & Komputer tidak mau hidup \\
\hline IF & $\begin{array}{l}\text { Baterai pada Laptop habis } \\
\text { kosong AND Ac Adaptor laptop } \\
\text { rusak: } \\
\text { a. lampu indikator listrik pada } \\
\text { laptop tidak menyala } \\
\text { b. tidak ada arus keluar dari kabel } \\
\text { output adaptor pada kabel power } \\
\text { laptop } \\
\text { AND Dc Jack terlepas/Rusak: } \\
\text { Dc jack merupakan komponen } \\
\text { yang terdapat pada laptop sebagai } \\
\text { lubang colokan antara listrik } \\
\text { dan laptop yang terletak pada } \\
\text { motherboard }\end{array}$ \\
\hline THEN & Laptop mati total \\
\hline IF & $\begin{array}{l}\text { RAM Rusak : } \\
\text { RAM merupakan tempat } \\
\text { penyimpanan sementara pada } \\
\text { laptop/pc } \\
\text { a. komputer sering mati tiba-tiba } \\
\text { atau mendadak } \\
\text { b. memori pada kompuer tidak } \\
\text { terdeteksi atau berkurang } \\
\text { c. saat komputer dihidupkan hanya } \\
\text { muncul layar hitam } \\
\text { d. komputer terasa lelet/lambat } \\
\text { AND RAM atau memory tempat } \\
\text { penyimpanan sementara baru }\end{array}$ \\
\hline
\end{tabular}

Tabel 2. Relasi Kerusakan dengan Solusi

\begin{tabular}{|c|l|l|}
\hline Rule & \multicolumn{1}{|c|}{ IF } & \multicolumn{1}{|c|}{ THEN } \\
\hline 1 & G001, G002, G003 & K001 \\
\hline 2 & G004,G005, G006 & K002 \\
\hline 3 & $\begin{array}{l}\text { G007, G008, G009, } \\
\text { G010 }\end{array}$ & K003 \\
\hline 4 & G011, G012, G013 & K004 \\
\hline 5 & $\begin{array}{l}\text { G008, G010, G014, } \\
\text { G015, G016 }\end{array}$ & K005 \\
\hline 6 & $\begin{array}{l}\text { G017, G018, G019, } \\
\text { G020, G021, G022 }\end{array}$ & K006 \\
\hline 7 & G018 & K007 \\
\hline 8 & $\begin{array}{l}\text { G023, G024, G025, } \\
\text { G026, G027, G028 }\end{array}$ & K008 \\
\hline 9 & G029 & K009 \\
\hline 10 & $\begin{array}{l}\text { G001, G002, G030, } \\
\text { G041 }\end{array}$ & K010 \\
\hline 11 & G034 & K011 \\
\hline 12 & G012,G013 & K012 \\
\hline 13 & $\begin{array}{l}\text { G003, G031, G032, } \\
\text { G037,G038 }\end{array}$ & K013 \\
\hline 14 & G001, G003, G030 & K014 \\
\hline & & \\
\hline
\end{tabular}


IN F O R M A T I A

Jurnal Informatika, Manajemen dan Komputer, Vol. 9 No. 2 , Desember 2017

eISSN : 1979-0694

pISSN : 1979-0694

\begin{tabular}{|l|l|}
\hline & diganti, tapi tidak sesuai dengan \\
jenis PC/Laptop \\
AND Boot sector pada harddisk \\
rusak : \\
gagal pada saat loading \\
windows/OS atau proses \\
penyimpanan data menjadi lambat \\
AND Ada bad sector pada track \\
awal harddisk : \\
a. Proses penyimpanan data \\
menjadi lambat \\
b. komputer sering hang/berhenti \\
saat penyimpanan data \\
berlangsung \\
namun laptop/pc tetap tidak \\
menyala \\
c. laptop/pc sering restart atau \\
mati mendadak \\
c. sering terjadi blue screen/ layar \\
biru pada laptop/pc \\
d. terdengar suara berisik pada \\
laptop/pc khususnya pada hardisk \\
e. loading lambat saat menyalakan \\
laptop/pc
\end{tabular}

\begin{tabular}{|c|c|}
\hline & $\begin{array}{l}\text { e. loading lambat saat menyalakan } \\
\text { laptop/pc } \\
\text { pada trek awal harddisk AND } \\
\text { Software mengalami crash : } \\
\text { aplikasi menjadi macet / berhenti } \\
\text { bekerja secara tiba-tiba, } \\
\text { biasanya tampil pemberitahuan } \\
\text { aplikasi berhenti bekerja } \\
\text { AND ketika penambahan } \\
\text { hardware baru Laptop/PC sering } \\
\text { terjadi konflik atau } \\
\text { laptop/pc menjadi hang atau } \\
\text { sering mati mendadak } \\
\text { AND Ada virus di harddisk }\end{array}$ \\
\hline THEN & Komputer sering "hang" \\
\hline IF & $\begin{array}{l}\text { Keyboard tidak terpasang dengan } \\
\text { benar AND Keyboard rusak AND } \\
\text { Setting/pengaturan Keyboard } \\
\text { tidak benar AND colokan usb } \\
\text { yang terhubung pada motherboard } \\
\text { terjadi kerusakan AND Driver } \\
\text { keyboard tidak cocok AND } \\
\text { Keyboard tidak terdeteksi pada } \\
\text { laptop/pc }\end{array}$ \\
\hline THEN & Keyboard tidak terdeteksi \\
\hline IF & Keyboard rusak \\
\hline THEN & $\begin{array}{l}\text { Beberapa tombol keyword laptop } \\
\text { berhenti bekerja }\end{array}$ \\
\hline IF & $\begin{array}{l}\text { Mouse tidak terpasang dengan } \\
\text { benar AND Mouse rusak AND } \\
\text { Setting/pengaturan Mouse tidak } \\
\text { benar AND colokan mouse yang } \\
\text { terletak pada motherboard rusak } \\
\text { AND Driver mouse tidak cocok } \\
\text { AND Mouse tidak terdeteksi }\end{array}$ \\
\hline THEN & Mouse tidak berfungsi \\
\hline IF & $\begin{array}{l}\text { Baterai Cmos mati : } \\
\text { a. settingan/pengaturan jam pada } \\
\text { laptop/pc tidak benar, tidak } \\
\text { mengikuti jam pada saat ini } \\
\text { b. saat loading windows terdapat } \\
\text { informasi/pemberitahuan setup } \\
\text { ulang pada BIOS }\end{array}$ \\
\hline THEN & $\begin{array}{l}\text { Jam dan setting } B I O S \text { selalu } \\
\text { berubah-ubah }\end{array}$ \\
\hline IF & $\begin{array}{l}\text { Koneksi kabel antara cpu dan } \\
\text { monitor sudah terpasang dengan } \\
\text { benar. AND Pemasangan kabel } \\
\text { pada sumber arus listrik/colokan } \\
\text { sudah terpasang dengan benar. } \\
\text { AND VGA Card rusak: }\end{array}$ \\
\hline
\end{tabular}


IN F O R M A T I A

Jurnal Informatika, Manajemen dan Komputer, Vol. 9 No. 2 , Desember 2017

eISSN : 1979-0694

pISSN : 1979-0694

\begin{tabular}{|c|c|}
\hline & $\begin{array}{l}\text { a. laptop/PC macet ketika berkerja } \\
\text { terutama saat edit video atau } \\
\text { memutar video dan memainkan } \\
\text { game } \\
\text { b. muncul gambar semu/garis- } \\
\text { garis pada laptop/PC } \\
\text { c. Monitor laptop/PC tidak } \\
\text { menampilkan gambar sama sekali } \\
\text { AND Slot VGA tidak terpasang } \\
\text { sempurna }\end{array}$ \\
\hline THEN & Monitor tidak menyala \\
\hline IF & $\begin{array}{l}\text { Set up driver untuk monitor tidak } \\
\text { tepat }\end{array}$ \\
\hline THEN & $\begin{array}{l}\text { monitor menjadi gelap saat } \\
\text { loading windows }\end{array}$ \\
\hline IF & $\begin{array}{l}\text { Harddisk bermasalah. AND } \\
\text { harddisk rusak. }\end{array}$ \\
\hline THEN & $\begin{array}{l}\text { monitor berkedip-kedip atau } \\
\text { muncul garis saat digunakan }\end{array}$ \\
\hline IF & $\begin{array}{l}\text { power supply rusak : } \\
\text { a. meskipun pemasangan kabel } \\
\text { sudah benar namun pc tetap tidak } \\
\text { menyala } \\
\text { b. lampu indikator pada cpu tidak } \\
\text { menyala } \\
\text { c. PC menyala tapi tidak mau } \\
\text { masuk ke windows } \\
\text { AND Jumper Cmos Motherboard } \\
\text { salah pasang : } \\
\text { Jumper digunakan untuk konektor } \\
\text { /penghubung sirkuit elektrik yang } \\
\text { digunakan } \\
\text { untuk menghubungkan atau } \\
\text { memutus suatu sirkuit, jumper } \\
\text { cmos biasanya terletak } \\
\text { didekat baterai cmos biasanya } \\
\text { terdapat tiga kaki/pin pada jumper } \\
\text { ini. } \\
\text { AND motherboard / papan induk } \\
\text { rusak AND Stroom listrik tidak } \\
\text { berfungsi AND Kabel power } \\
\text { switch casing belum/salah pasang } \\
\text { pada motherboard }\end{array}$ \\
\hline THEN & $\begin{array}{l}\text { ketika menekan tombol power, } \\
\text { Power/ stroom listrik tidak } \\
\text { muncul, kipas power suply tidak } \\
\text { hidup }\end{array}$ \\
\hline
\end{tabular}

\section{f. Pohon Keputusan Pakar}

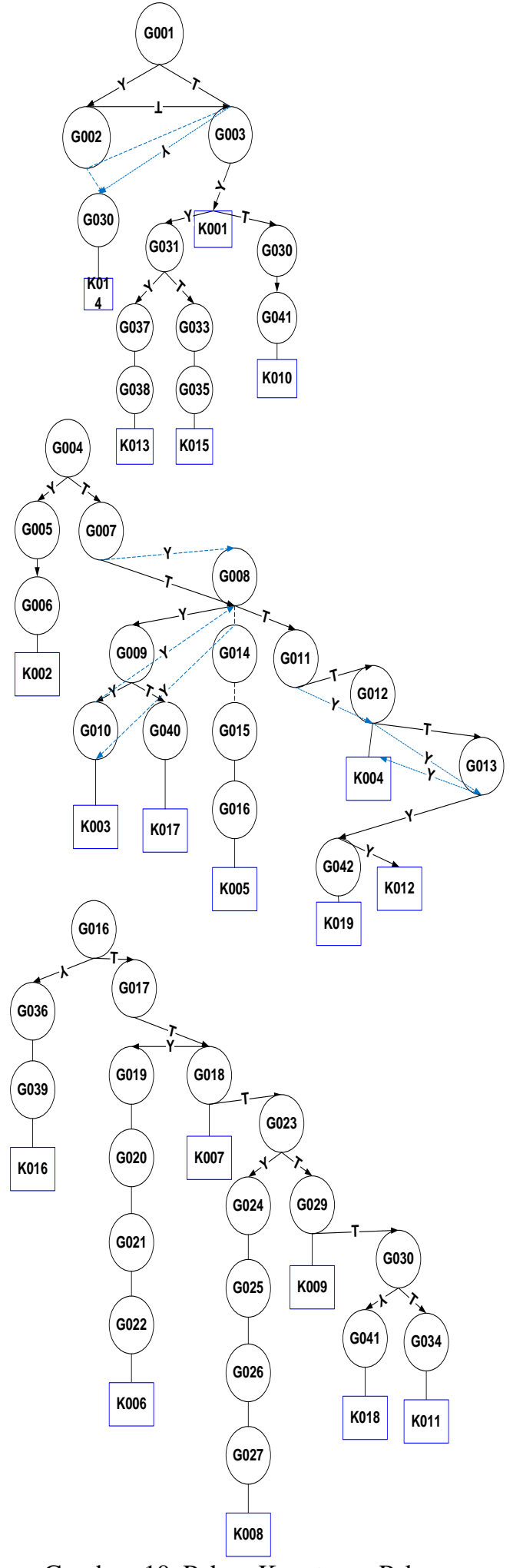

Gambar 10. Pohon Keputusan Pakar 
I N F ORM A T I R

Jurnal Informatika, Manajemen dan Komputer, Vol. 9 No. 2 , Desember 2017

eISSN : 1979-0694

pISSN : 1979-0694

\section{g. Hierarki Input Proses Output User}

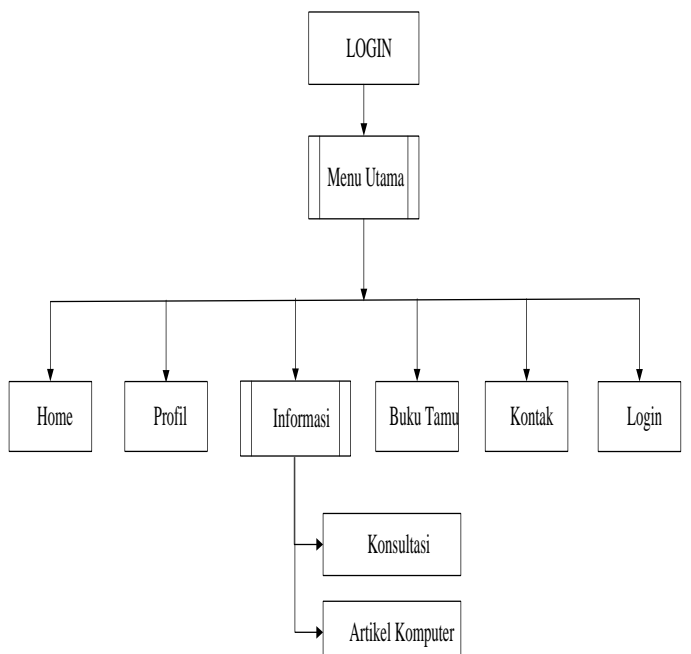

Gambar 12. Hierarki Input Output Admin

\section{h. Implementasi Sistem}

Jika kita sudah melakukan login kita akan diahlikan ke form administrator. Berikut tampilan form administrator yang mana pada form ini terdapat beberapa menu dan submenu yang memiliki fungsi dan kegunaan masingmasing.

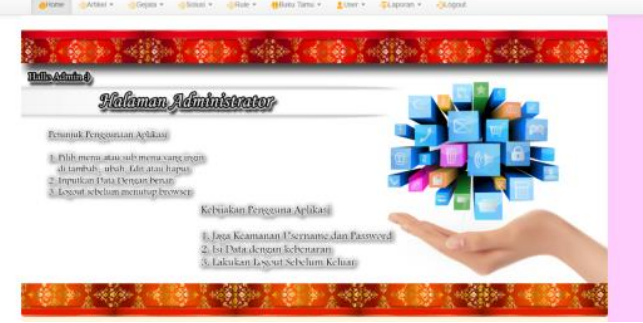

Gambar 13. Form Menu Admin

\section{Form Menu Utama}

Berikut ini adalah tampilan form utama. Dimana ketika user membuka aplikasi akan menampilkan form ini. Pada form ini user dapat mengakses beberapa menu dan submenu yang memiliki fungsi masing masing diantaranya, user dapat melakukan konsultasi mengenai kerusakan yang dialami user pada menu informasi dan submenu konsultasi.

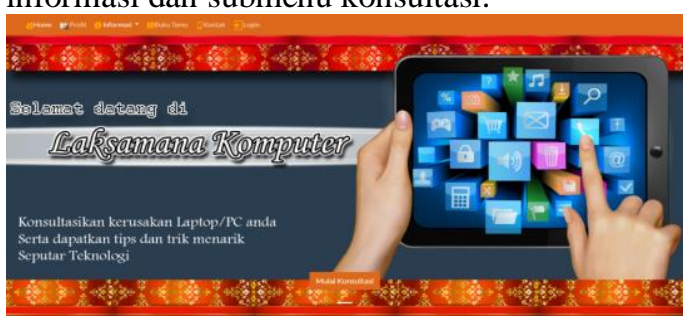

Gambar 14. Form Menu Pengguna

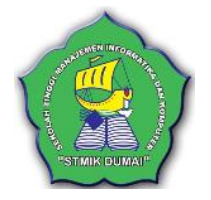

2. Form Input Gejala

Form ini terletak pada menu gejala dan submenu entri gejala, pada form ini digunakan untuk input data gejala, adapun cara menggunakan form ini sebagai berikut :

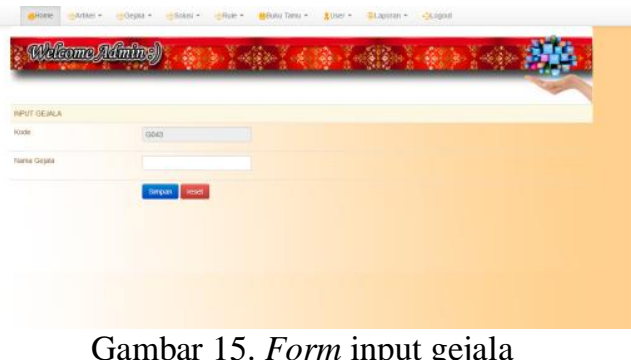

3. Form Input Solusi

Form ini terletak pada menu solusi dan submenu entri solusi, form ini digunakan untuk menginput data solusi, adapun cara menggunakan form ini sebagai berikut:

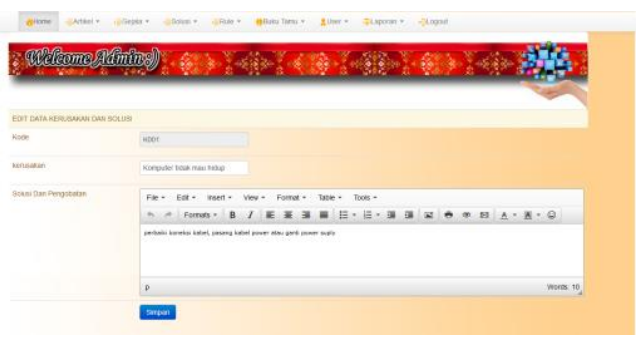

Gambar 16. Form Input Data Solusi

4. Form Input Rule

Form ini untuk menghubungkan data kerusakan dan data gejala, klik menu rule dan submenu entri rule maka akan tampil form sebagai berikut :

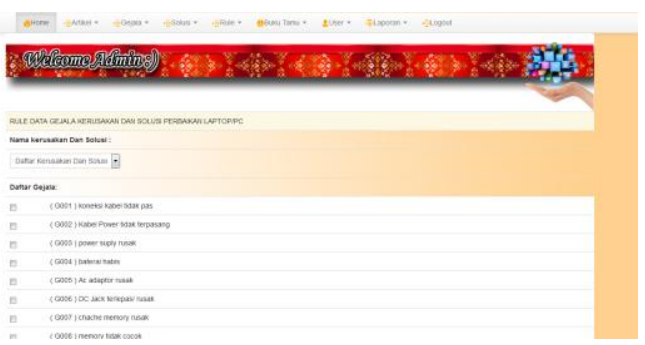

Gambar 17. Form Input Rule

5. Form Proses Daftar Konsultasi

Form ini terletak pada menu form informasi dan submenu konsultasi, form ini merupakan proses awal konsultasi, cara melakukan konsultasi dapat dilakukan sebagai berikut: 
IN F O R M A T I A

Jurnal Informatika, Manajemen dan Komputer, Vol. 9 No. 2 , Desember 2017

eISSN : 1979-0694

pISSN : 1979-0694

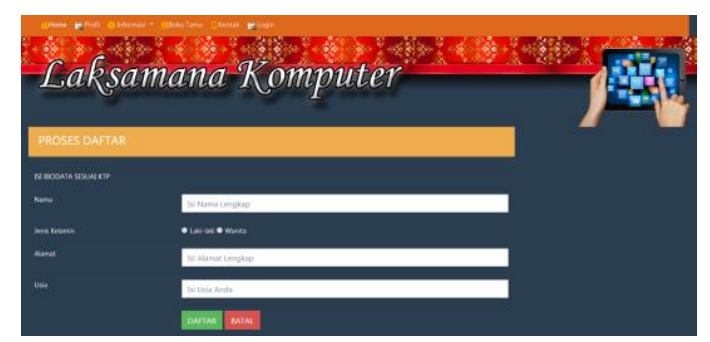

Gambar 18. Form Proses Daftar Konsultasi

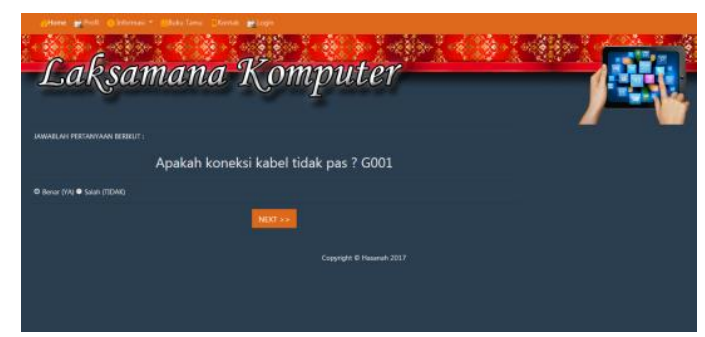

Gambar 19. Form Proses Konsultasi

Pada form ini, jawab pertanyaan sesuai dengan kerusakan, kemudian klik tombol lanjut untuk pertanyaan berikutnya.

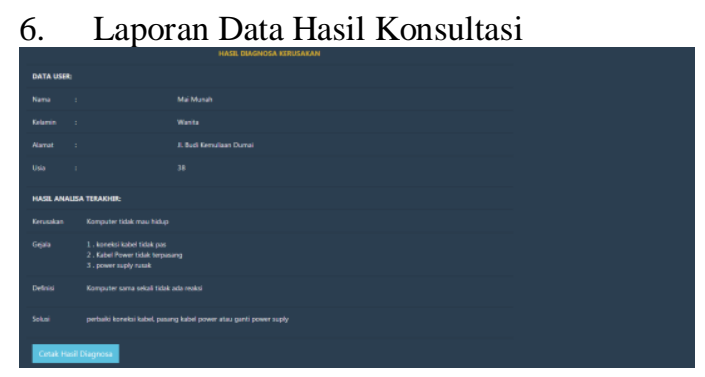

Gambar 20. Laporan Data Hasil Konsultasi

7. Laporan Data Konsultasi Per Periode

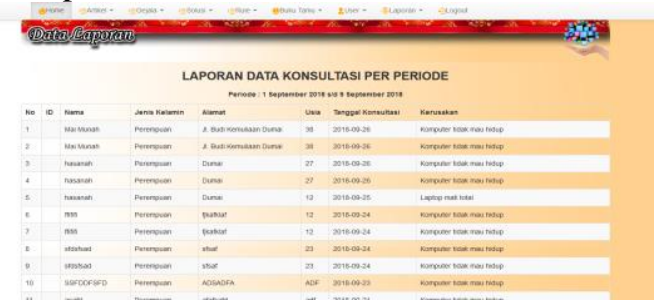

Gambar 21. Laporan Data Hasil Konsultasi

8. Laporan Data Gejala

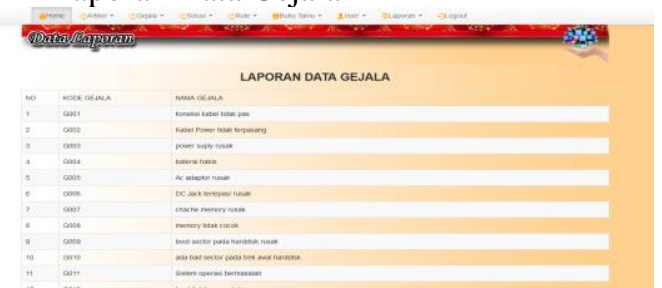

Gambar 22. Laporan Data Gejala

9. Laporan Data Kerusakan dan Solusi

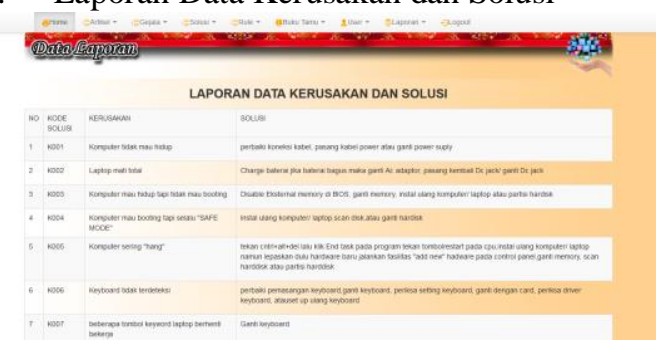

Gambar 23. Laporan Data Kerusakan dan Solusi

\section{KESIMPULAN}

Dari hasil penelitian yang dilakukan, maka dapat diambil beberapa kesimpulan sebagai berikut :

1. Dengan menggunakan aplikasi sistem pakar khususnya aplikasi pendeteksi kerusakan laptop/PC, dapat mempermudah masyarakat dalam memperbaiki kerusakan pada perangkat komputer mereka.

2. Dengan sistem yang terkomputerisasi masyarakat dapat mendeteksi kerusakan pada laptop/PC mereka dengan lebih cepat.

3. Membantu perusahaan dalam meningkatkan pelayanan sehingga dapat meningkatkan kepuasan pada masyarakat, Sehingga dapat menjadi nilai tambah dimata masyarakat dan dalam mempromosikan perusahaan.

\section{REFERENSI}

Abdul Kadir. (2013). Pemrograman Database mysql untuk Pemula. Jakarta: Mediakita.

Achmad Solihin. (2010). Mysql 5 Dari Pemula Hingga Mahir. Jakarta: Achmatim.Net.

Annisaa, R., \& Hidayatullah, R. (2017). Aplikasi Pembelajaran Bahasa Inggris Disertai Kamus. Jurnal Informatika, Manajemen Dan Komputer, 9(1), 36-43. Retrieved from http://www.ejournal.stmikdumai.ac.id/ind ex.php/path/article/view/62

Cilla Mondev, A., Asparizal, \& Adrianto, S. (2017). Komputerisasi Barang Inventaris Pada Kantor Lingkungan Hidup Kota Dumai. Informatika, Manajemen Dan Komputer, 9(1), 1-9. Retrieved from http://www.ejournal.stmikdumai.ac.id/ind ex.php/path/article/view/57

Rosnelly, R. (2012). Sistem Pakar Konsep dan Teori. Yogyakarta: Andi. 
INFORM T IK A

Jurnal Informatika, Manajemen dan Komputer, Vol. 9 No. 2 , Desember 2017

eISSN : 1979-0694

pISSN : 1979-0694

Setyaji, J. (2010). Buku Pintar Menguasai

Komputer dan Laptop. Jakarta: Mediakita.

Sutojo, T, E. M. \& V. S. (2011). Kecerdasan

Buatan. (Benedicta Rini W, Ed.).

Yogyakarta: Andi. 